Fotografia: Sílvia Aguião.

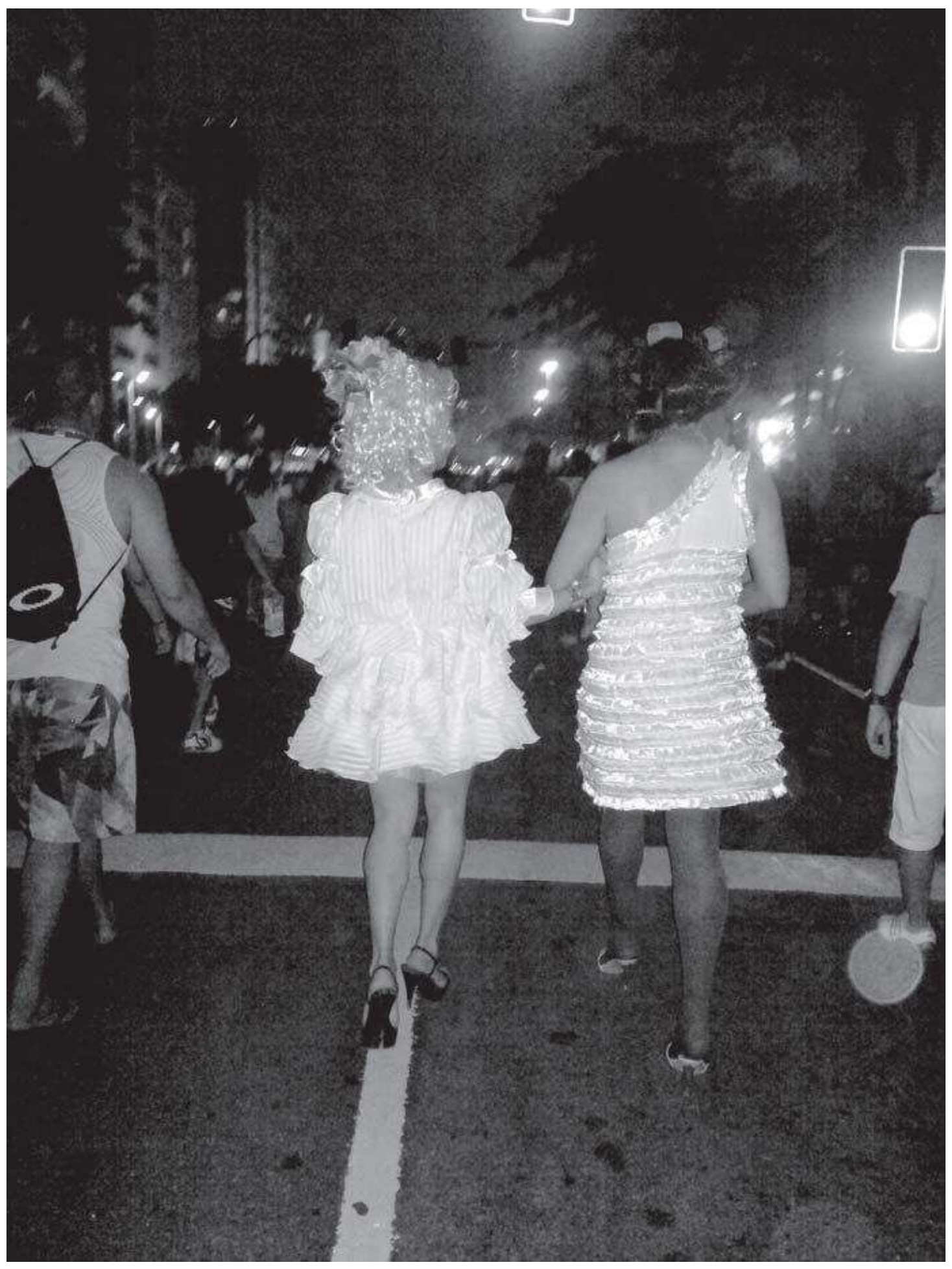




\title{
Objetivação de direitos nos limites do capital e lutas sociais: contribuições do debate contemporâneo para o Serviço Social
}

\author{
FORTI, Valeria; BRITES, Cristina M. (Orgs.) Direitos humanos e serviço social: \\ polêmicas, debates e embates. Rio de Janeiro: Lumen Juris, 2011.
}

Maria Raimunda Penha Soares*

Quais contribuições o debate contemporâneo sobre os Direitos Humanos, elucidando suas polêmicas e contradições, pode trazer para o assistente social em seu trabalho cotidiano, de forma que a expressão "sujeitos de direitos", como destacam Forti et al. (p. 49), tão utilizada pelos profissionais do Serviço Social, seja apreendida em suas configurações históricas e não de forma abstrata?

O livro Direitos humanos e serviço social: polêmicas, debates e embates, organizado por Valeria Forti e Cristina Brites, reúne diversos artigos que, a partir de abordagens diferentes, mas dentro de uma perspectiva crítica marxista, trazem elementos importantes para o debate contemporâneo sobre os diretos humanos. Elementos que permitem uma análise que, dentre outras contribuições, desmistifica a concepção de universalidade dos direitos humanos, denunciando, assim, os limites da sociabilidade do capital e apontando para o rompimento do caráter reificado da "modalidade de enfrentamento da questão social no campo contraditório de negação e afirmação de direitos", como acentua Gomes (108).

A contradição material da reprodução social nas sociedades de classes, solo histórico sobre o qual surgem e, em alguns casos, se consolidam alguns direitos humanos, é a mesma que sustenta a convivência entre violações históricas desses direitos e seu desenvolvimento no plano jurídico e institucional. No prefácio do livro, J. Damião Trindade demonstra que ainda há um abismo descomunal entre as "normas protetivas dos direitos humanos" e sua real efetividade social.

De forma geral, os autores apontam para duas questões essenciais sem as quais não se pode apreender a concepção e a dinâmica contemporânea dos direitos

\footnotetext{
*Assistente social e economista, doutora em Serviço Social (UFRJ) e professora adjunta do Curso de Serviço Social do Departamento Interdisciplinar de Rio das Ostras (RIR), da Universidade Federal Fluminense - Polo Universitário de Rio das Ostras (PURO/UFF).
} 


\title{
heVistg a III Pautg
}

\section{R E S E N H A}

humanos na sociedade burguesa: a primeira é a incompatibilidade entre o capitalismo e a garantia dos direitos humanos ou a impossibilidade de "universalização de todos os direitos humanos sobre o modo de produção capitalista". A segunda é a necessidade da luta social como forma de garantia de direitos ou a relação direta entre garantia de direitos e classes sociais (lutas de classes).

A incompatibilidade entre capitalismo e direitos humanos, como acentua lasi, não deve gerar nenhuma "postura paralisante", pois ela apenas indica que:

\begin{abstract}
esses direitos, a vida o vem demonstrando, não são 'universais', valem apenas para uma parcela da universalidade humana, a parcela rica, e não para as multidões de pobres ou de desempregados (a estes, no máximo, o assistencialismo público ou a caridade privada), nem para as pessoas com biótipos não caucasianos e idiomas não europeus (TRINDADE, p. 26).
\end{abstract}

Desta forma, "as bases reais da produção da desigualdade, do ponto de vista dos direitos conquistados, historicamente só podem ser enfrentadas parcialmente, visto que sua reprodução ampliada é necessária à manutenção da sociabilidade burguesa", nas palavras de Brites (p. 61).

Por outro lado, foram as lutas históricas das classes trabalhadoras que demarcaram no campo prático as conquistas pela garantia e ampliação de direitos. Como nos indica Brites (p. 65), "os movimentos sociais foram e são uma das forças políticas mais expressivas para a ampliação dos direitos, da cidadania e da democracia no interior da sociabilidade burguesa". Desta maneira, é a "correlação de forças estabelecida na luta de classes", a "capacidade de mobilização e ação dos movimentos sociais e populares", de um lado, e "a resistência das classes dominantes", do outro, que determinam, contraditoriamente, o ritmo dos direitos (IASI, p. 185).

Estes dois elementos - os limites do capital e as lutas sociais - demonstram que a luta pela efetivação de direitos dentro da sociedade burguesa deve ultrapassar o "respeito aos conteúdos mínimos dos direitos que já estão formalmente consagrados", mas se direcionar para o "desenvolvimento dinâmico dos seus significados e pela consagração de novos direitos" (MARQUES, p. 207), bem como apontar para o caminho da emancipação humana, o que implica, necessariamente, a superação da sociedade capitalista.

Se a garantia de direitos humanos na sociedade burguesa esbarra nos limites do capital, não se pode negar que "as lutas pelos mesmos possibilitam afirmar a importância da resistência em face do avanço das diversas formas de desumanização que temos assistido". Trata-se de resistência às formas contemporâneas de criminalização da pobreza e dos movimentos sociais, bem como da potencialidade que essa luta tem de "fortalecer ações de denúncia sobre violações e aviltamentos contra a dignidade humana e dar visibilidade a práticas voltadas para o reconhecimento social de muitos segmentos oprimidos". (FREIRE, p. 167).

Enfim, o livro Direitos humanos e serviço social: polêmicas, debates e embates traz contribuições significativas para superar a concepção abstrata de direitos 


\section{ReViStg RII PaUtd}

\section{R E S E N H A}

humanos no trato profissional cotidiano das diversas expressões da questão social. Por outro lado, aponta para uma apropriação crítica das mediações existentes entre efetivação de direitos e lutas de classes. Se a efetivação de direitos humanos na sociedade burguesa esbarra nos limites do capital, tornando possível, social e historicamente, apenas a emancipação política (um avanço dentro desta sociedade), a emancipação humana, como indica lasi (p. 188) "é a possibilidade de expressão de uma sociabilidade que se coloque contra e além do capital". 